\title{
Fiscal potential of the investment mechanism of Islamic Finance
}

\author{
Aliev Ayaz Aladdin ${ }^{1}$, Mikhail Gordienko ${ }^{1}$, Veronika Nekrasova $^{1}$, and Allahverdi Farzaliyev Javid ${ }^{1}$ \\ ${ }^{1}$ Department of financial management, Plekhanov Russian University of Economics, Prague, Moscow Russian Federation
}

\begin{abstract}
Abstract-the Research focuses on the application of Islamic Finance abroad, as well as in Russia. The authors present the history of Islamic Finance, its restrictive principles, and analyze in detail the majority of Islamic investment contract models. As such, the following were considered separately: partnership (Mudaraba, Musharaka, Agency-Wakala), acquisition (deferred payment sale-Murabaha, musavami and tawarruk, deferred delivery sale-Salam, delivery-istijrar, contract - istisnaa), lease (Ijara), credit operations (loan-Kadr, debt transfer-hawala, debt sale-Bai-al-DIN), public promise of a reward or competition (juaala), as well as financial instruments (sukuk). It is pointed out that the fiscal potential does not fully allow stimulating the use of models, and requires further development both from the point of view of tax and non-tax (quasi-fiscal) payments of the corporate sector of the state economy. The paper considers the classical model for evaluating financial assets with a tax corrector, as well as the standard approach to assessing the effect of financial leverage, which require modification in the absence of loan interest, as well as the task of stimulating economic activity in the post-quarantine period. In the final part, we describe the prospects and formulate forecasts for the application of the principles of Islamic Finance in Russia.
\end{abstract}

\section{Introduction}

Islamic Finance is an integral part of the Islamic economy - a system of management based on the norms and principles of Muslim law. The Islamic Finance market is one of the most dynamically developing modern financial markets. The volume of Islamic financial assets in global financial markets increased from $\$ 509$ billion in 2006 to $\$ 2.5$ trillion in 2018, showing an increase of more than $450 \%$ over 12 years. In 2018, Islamic financial assets accounted for almost $3 \%$ of the global financial market and their growth rate since their appearance in the $70 \mathrm{~s}$ of the twentieth century. they practically did not decrease, remaining at the level of $15-20 \%$ per year [1]. With the growth of assets, Islamic banks are becoming more confident in integrating into the international financial system. The impressive growth rate of this market and the growing demand for Islamic financial products not only from the Muslim world causes increased interest of specialists in the study of this phenomenon.

For Russia, it is important to assess the possibility of applying Islamic investment contract models from the point of view of their complementarity with the existing financial system, as well as their effectiveness. An important issue remains the task of stimulating the use of such models by fiscal instruments of the corporate sector [2].

\section{Research methodology}

The research tools are based on the use of standard research methods: system, historical, analytical, coefficient, statistical.

The sources of the research were: the report of a financial technology solutions provider linking the global Islamic financial market DDCAP Group for 2019Islamic Finance Country Index 2019, as well as a number of scientific publications by Russian University scientists, as well as materials from the Institute of Eastern Countries [3].

In the framework of the classical approach, we first analyze the retrospective experience of Islamic banking, describe the main financial mechanisms and the possibility of their fiscal incentives, and make forecasts for Russia.

\section{Discussion of the results}

\subsection{History of Islamic banking}

The Islamic type of banking model is based on the religious principles of Islam. Since the advent of Islamic civilization, there have been operations such as currency exchange, money transfers, and the use of cheques. As a result of colonial expansion, Muslim countries assimilated the Western banking model, and Islamic banking, which appeared in the early period of Islam, ceased to exist [4]. 
Significant changes occurred only at the beginning of the twentieth century. At that time, there were about 1/5 of the world's population who professed Islam. All Islamic countries were developing countries, and they were characterized by a high degree of social stratification with a large proportion of the poor population. On the one hand, the traditional Western banking model has failed to win the full trust of Muslim entrepreneurs and citizens. On the other hand, the accumulation of savings was impossible not only because of the low incomes of the majority of the population, but also negatively assessed by the General norms of Islamic ethics. Nevertheless, the reserves" for a rainy day", which even the most poorly provided citizen tries to create, according to some estimates, totaled hundreds of billions of dollars [5].

In an attempt to attract these funds into economic circulation, Islamic economists proposed creating a new financial system that conforms to the norms of Islam. Real Islamic banks began to appear in the 1970s as part of the growth of Arab identity, oil enrichment of the monarchies of the Arabian Peninsula, the Islamic revolution in Iran, and the processes of modernization and Islamization of the economy in a number of countries in Asia and Africa [6].

\subsection{Restrictive principles of Islamic Finance}

The modern movement of Islamic Finance is based on the belief that all forms of interest are RIBA (Arabic. Ül-growth, increment, increase, usury) and, therefore, are prohibited. In addition, Islamic law prohibits investment in businesses that are considered illegal or Haram. This includes selling alcohol or pork, or investing in media such as gossip columns or pornography that contradict Islamic values. In addition, what is called maisir and garar is forbidden. Maisir refers to contracts in which ownership of a commodity depends on the occurrence of a pre-determined, uncertain event in the future, while garar describes speculative operations. Both concepts involve excessive risk and uncertainty, thus excluding fraudulent activities. Consequently, it is impossible to use all traditional derivatives of economically developed countries in Islamic banking [7].

\subsection{Islamic investment contract models}

Islamic banking has the same goals as traditional banking: to earn money for a banking institution by borrowing capital in accordance with Islamic law. Since Islam prohibits the usual borrowing of money at interest, Islamic rules for making transactions, known as fiqh alMuamalat, were developed. The main principle of Islamic investment is based on risk allocation, which is a component of trading, and not the transfer of risk provided for by traditional banking.

Financial institutions differ significantly from classical banks in their organizational structure and the nature of their transactions, due to the fact that they carry out all operations on an interest-free basis. Let's consider the main contractual models [8].

1) Partnership.

a) Mudaraba. It is an approximate analogue of a limited partnership, when the participation of one party is limited to the provision of capital, and the othercapital management. The losses are only on account of the party providing the capital (rubberman). The liability of this party is limited to the amount of funds provided. With the permission of rabulan managing partner is entitled to invest in joint activities.

(b) Musharaka. Agreement on joint activities. One of the partners may refuse to personally manage the joint activity. It is possible to pay remuneration to the managing partner before dividing the profit from joint activities. Shrinking Musharaka. An agreement that provides for the gradual purchase of a share in a joint operation by one of the partners.

c) Agency (Wakala). Appointment of an agent acting on behalf of the principal for a certain fee.

2) Acquisition (purchase and sale transactions).

a) Sale with deferred payment.

* Murabaha. The contract allows for a surcharge for deferred payment. A condition of Murabaha is that the seller discloses information about the spot price of the product and the mark-up for the delay. Reverse sales are prohibited.

In musawama. It differs from Murabaha in that the seller is not required to disclose the amount of the markup for deferred payment.

In tawarruq (reverse Murabaha). The buyer under the murabahi agreement simultaneously sells the product at the spot price to a third party and receives the difference between the spot price and the deferred payment price.

b) Sale with deferred delivery (Salam). A contract may be concluded for goods that have generic characteristics. A repurchase clause in the contract is prohibited. However, the seller and the buyer can enter into a separate agreement on the return sale after the actual delivery of the goods. Resale of the product before it is received by the buyer is prohibited. The buyer has the right to enter into a so-called parallel Salam with a third party. It is allowed to secure the seller's liability by collateral or otherwise [9].

c) Delivery (istijrar). The contract provides for a continuing relationship between the supplier and the buyer, in which the supplier from time to time delivers products to the buyer at the price agreed upon in the contract.

d) Contract (istisnaa). A contract to create products and then transfer them to the customer at a predetermined price. Payment can be made in installments. The buyer can enter into a so-called parallel agreement with a third party. It is possible to provide for a reduction in the price for late delivery of goods.

3) rent (Ijara). On the basis of Ijara, the lessee transfers the right to use and extract income from the item. The contract may provide for the possibility of sublease. A lease with the right to buy out or a reservation on the transfer of property to the lessee at the end of the lease agreement is possible. The assignment of rent payments is possible at their nominal value. 
4) Credit operations (loan).

a) a Loan (the frame). The loan is repaid upon request. Interest on loans is prohibited. A gift to the lender is allowed, but it is forbidden to make the loan conditional on the mandatory presentation of a gift.

b) transfer of debt (hawala). According to most scientists, the creditor does not have the right to challenge the transfer of debt to a wealthier debtor.

c) sale of debt (Bai-al-DIN). Selling debt to a third party at a discount is prohibited, according to most scientists. According to a minority of scientists, it is allowed for cases of commodity credit (delivery with deferred payment). In this case, the discount is not a loan interest, but a share of the profit.

5) a Public promise of an award or competition. Jwala. In this transaction, one party (ja'il) undertakes to pay remuneration to any person who has achieved a certain or definable result.

6) Financial instruments. Sukuk. Equity participation certificate, an asset-backed security. The turnover of sukuk depends on the types of assets in providing

D. The fiscal potential of the model.

Classical approaches of economically developed countries are based on the use of not only own, but also borrowed capital of the investor. The classic financial asset pricing model (CAPM) is calculated as:

$$
E R_{i}=R_{f}+\beta_{i}\left(E R_{m}-R_{f}\right)
$$

$E R_{i}$ is expected rate of return on a long-term asset; $R_{f}$ is risk-free rate of return; $\beta_{i}$ is the coefficient of sensitivity of the asset to changes in market returns.

Depending on the availability of borrowed funds, the BPI is calculated either with or without the leverage factor. The main thing is that in any of the calculation approaches there is a tax corrector $(1-\mathrm{T})$, where $\mathrm{T}$ is the income tax. In addition, the tax corrector itself is also present when calculating the effect of financial leverage, which takes into account the fact that borrowed funds are used to increase the size of operations and profits in the absence of sufficient capital for this purpose:

$$
\mathrm{DFL}=(1-\mathrm{T})(\mathrm{POA}-\mathrm{p})(\Delta / \mathrm{E})
$$

DFL is financial leverage effect, as a percentage; ET is income tax rate, in relative value; POA is return on assets (economic return on EBIT) in\%; $p$ is interest rate on borrowed capital, in $\% ; \Delta$ is borrowed capital; $\mathrm{E}$ is equity.

Given the fact that there is no loan interest in Islamic Finance, the effect of financial leverage in such companies will not be manifested. At the same time, the use of credit contractual models, for example, sukuk-it is important to maintain and strengthen the interest of the company's management in using these models through additional effects from their application. When applying these models, we suggest that the structure of the tax corrector $(1-\mathrm{T})$ should take into account not only income tax, but also non-tax payments paid by the company that reduce the tax base on profit. A separate issue is the codification and systematization of such nontax payments [10].
The state is potentially interested in using the mechanism of Islamic Finance, since they exclude the growth of the money supply without increasing the real sector of the economy with all the positive derivative effects. The tax and non-tax mechanisms presented by the authors should stimulate debt-free development of economic entities.

\section{Conclusions}

Experts believe that Islamic banking can have good prospects in Russia, where 15\% of the population (more than 21.5 million people) are Muslims. It can help some Russian banks diversify their business and become more competitive. However, while there is no pure Islamic banking in Russia, there is also no necessary legal framework for it.

Attempts to introduce Islamic banking in Russia were made, but for various reasons ended in failure. Thus, in 1991, the Bard Forte Bank was established, which used the Islamic principles of banking that do not contradict the legislation of Russia. The Bank intended to start working with individuals in accordance with Sharia law. However, in December 2006, the Bank's license was revoked for "gross violations of the legislation on combating money laundering, as well as non-compliance with the requirements of The Bank of Russia's regulations".

The Dagestan Bank "Express" produced a credit card, a fee for the service which was transferred for charitable purposes. This product was recognized as compliant with Sharia law, but this Bank also had its license revoked in 2013 for submitting false reports [11].

To date, the only domestic Bank that has made a number of Islamic transactions is AK bars Bank. In 2011, the Bank completed its first public transaction, which raised \$ 60 million. In 2013, AK bars Bank attracted \$ 100 million to the economy of Tatarstan, which was provided by a group of international banks in accordance with Sharia law. Both projects are syndicated loans based on Murabaha principles, i.e. a purchase and sale transaction with deferred payment. The funds received under the project were used to Finance infrastructure projects.

According to the IFCI report, only 5 countries have seen their IBF (Islamic Banking and Finance) ratings decline over the past 8 years, namely Russia, Senegal, Syria, the UK and the US [12].

As already noted, transactions with Islamic banks in Russia are almost not carried out due to restrictions in the legislation. According to the Civil code, the use of credit provides for mandatory payment of interest, as well as liability for non-fulfillment of monetary obligations in the form of interest on the amount of these obligations. Articles 5 and 29 of the Federal law "on banks and banking activities" also state that interest is the only possible tool for increasing funds of both a credit institution and its clients. In this regard, the Association of Russian banks (ARB) proposes to introduce a number of amendments to the legislation and Supervisory practice of the Bank of Russia concerning 
Islamic banking, in particular, to recognize income received from activities in compliance with Islamic principles as interest-bearing in form or to provide for the possibility of lending without interest. In addition, the ARB took the initiative to adopt the law "on Islamic Finance", which could become the legal basis for the development of Islamic banking in Russia [13].

A serious obstacle in the legal regulation of Islamic Finance is the lack of legally established terminology on Islamic Finance in the Russian legal field, as well as analogs of concepts used in international practice for practices that comply with Islamic principles. Nevertheless, AK bars Bank managed to conduct the transaction by combining English law, which is mainly applied in international capital markets, with Sharia principles and Russian legislation [14].

Another factor hindering the development of Islamic banking in Russia is the lack of public awareness about the methods, mechanisms, and advantages of Islamic banking operations, which limits the demand for such services. In addition, the word "Islamic" for the Russian layman has acquired a negative connotation [15].

The most promising tools of Islamic banking in Russia are considered by experts to be Murabaha (sale with deferred payment), which is analogous in Russian practice to commercial credit; Mudaraba and Musharaka (trust and joint management); Takaful (insurance) and sukuk [16].

On the territory of Russia, the most promising regions for attracting Islamic Finance and developing Islamic banking are Bashkortostan and Tatarstan. The diversified and developed economy of these republics, the presence of significant hydrocarbon and certain gold reserves, as well as modern petrochemical and high-tech industrial production make the region attractive to middle Eastern investors [17].

Over the past six years, Kazan has become the main platform for Russia's interaction with Muslim countries in the framework of the International economic summit of Russia and the Organization of the Islamic conference (KazanSummit), which brings together Ministers of the Islamic world, representatives of Islamic financial organizations, parliamentarians and businessmen. In the first years of KazanSummit, theoretical aspects of the development of the Islamic financial model were discussed, and today these are concrete practical steps [18].

The infrastructure of Islamic Finance in Tatarstan now includes the Islamic business and Finance development Fund (IBFD Fund), the Tatarstan international investment company (TMIC), the Eurasian leasing company (EALC), the AK bars Bank, the Amal financial house, the Alliance Life insurance company, and a number of other organizations. The Russian center for Islamic Economics and Finance (RCIEF) operates as an educational platform. This suggests that the Foundation of the Institute of Islamic Finance in Russia is being laid in Tatarstan.

As a rule, two possible options are considered for the establishment and development of the Islamic financial system and the introduction of ethical business standards. One option is the example of Kazakhstan, where the Islamic financial system was launched by the political will of the country's President and the adoption of a law regulating Islamic Finance and banking. Another option is that first the practice of using Islamic financial instruments is formed within the framework of existing legislation, and then the necessary legal framework is formed on this basis.

Russia, according to experts, is currently moving along the second path. It should be noted that recently the structures regulating the Russian financial market have also begun to show interest in Islamic financial practices. So, in 2014, the Central Bank of Russia initiated a request to all banks in the country to identify problems related to the implementation of "elements of Islamic banking".

Against the background of the regime of Western sanctions against Russia, Islamic banking should be considered as an effective alternative to replacing Western usurious financial resources. In addition, Islamic banking, as an alternative to traditional banking, has shown better stability and resistance to financial crises. In this context, Islamic banking is an effective innovation in banking.

\section{References}

1. A.I. Zhuravlev, Theory and practice of Islamic banking, 244 (Moscow: Institute of Oriental studies of the Russian Academy of Sciences, 2002).

2. Zh. Igoshina, Islamic banking-as a financial instrument. - 03.11.2013. - access Mode: http://smart-lab.ru/blog/148879.php

3. S. Iskakov, About the world market of Islamic securities. - access Mode: http: / / www.islamnews.ru/news-26507.html

4. the index of the countries of Islamic Finance - IFCI 2019/ URL: http://www.gifr.net/publications/gifr2019/ifci.pdf

5. Islamic banking is an effective innovation in banking: Interview of the Chairman of the Parliament of the Chechen Republic D. Abdurakhmanov - - 28.11.2014. - access Mode: http://islamic-finance.ru/news/2014-11-28-1307

6. Islamic banks / / business Expert. - Mode of access: http://expbiz.ru/biznes-stati/bankovskayadeyatelnost/islamskie-banki.html

7. Islamic financial and credit institutions in the economy of foreign countries / R. I. Bekkin, R. R. Vakhitov, G. T. Gafurova and others / ed. By V. G. Timiryasov. - Kazan: publishing house "Cognition" of the Institute of Economics, management and law, 2011. - 236 p.

8. L. Makeeva, Islamic Finance is ready to go to the Russian economy. - Mode of access: http://islamicfinance.ru/board/2-1-0-18

9. A. Nigmatzyanova, Islamic banking: development and prospects. - DOS-Tupa mode: http://islamicfinance.ru/board/2-1-0-20 
10. V. Kolmakov, K. Ekimova, K. Ordov, A. Aliev, N. Chuikova, Influence of monetary policy on the competitiveness of companies through the credit channel, European Research Studies Journal, 21(4), 614-623 (2018).

11. A.A. Aliev, T.G. Bondarenko, I.T. Keri, A. U. Soltakhanov, A.A. Vershinina, Forecasting levels of innovative development on the example of the state oil company, Journal of applied economic Sciences, 13(7), 1902-1907 (2019)

12. N. Gryzunova, E. Shuvalova, A. Polyakova, K. Kerimov, Competitiveness of companies as the most important goal of national monetary policy in the context of financial globalization, Journal of applied economic Sciences, 12(6), 1585-1592 (2017).

13. V. Yu. Morozov et al., Formation of a human resource management system in organizations, European Research Journal, 20(3), 325- 337 (2017).

14. M. Jamrisko, W. Lu, These are the most innovative economies in the world. Official website of Bloomberg. Available at: https://www.bloomberg.com/news/articles/2017-0117/sweden-gains-south-koreareigns-as-world-smost-innovative-economies (2017)

15. E. Shuvalova, Yu. Zakharova, N. Sibatulina, Economic and environmental goals of the oil and gas industry development. International interdisciplinary conference GeoConference SGEM, 17(5.4), 275-282 (2017)

16. O. Romanchenko, O. Shemetkova, V. Pyatanova, D. Kornienko, Approach to the assessment of the fair value of assets in the cryptocurrency market, Advances in intelligent systems and computing, 850. 245-253 (2019).

17. Y. Ivanova, V. Nikeryasov, N. Balikhin, A. Savlukov, Ways of improvement of system of the taxation replacement of minerals: the example of Commonwealth of Independent States, International journal of energy Economics and policy, 8(5), 97103 (2018).

18. S. Valentey, Counter-Innovation environment of the Russian economy, Economic issue, 2005(10), 132143 (2005). 